\title{
A new species of Moraria (Crustacea: Copepoda: Harpacticoida) from the Laurentian Great Lakes
}

\author{
JANET W. REID ${ }^{1} \&$ LYNN T. LESKO ${ }^{2}$ \\ ${ }^{1}$ Research Associate, Division of Science and Learning, Virginia Museum of Natural History, Martinsville, \\ Virginia; Correspondence Address: 1100 Cherokee Court, Martinsville, VA 24112-5318, USA; email: \\ jwrassociates@sitestar.net \\ ${ }^{2} 11123$ Boyce Road, Chelsea, MI 48118, USA; email: ltlesko@netzero.net
}

\begin{abstract}
Moraria hudsoni n. sp. is described from Trails End Bay in Lake Michigan and Prentiss Bay in Lake Huron, Michigan, USA. The new species differs from its congeners in chaetotaxy, body ornamentation, and other characters. We review published records of members of Moraria from North and Central America; no species is known from South America. Species of this genus have been found in the mountains of southern Mexico, Guatemala, and Honduras, but none of these has been validly described. In North America, eight species have been recorded from Alaska, Canada, and the conterminous USA as far south as North Carolina. We report new geographical records of $M$. affinis from Virginia, and of both M. cristata and M. virginiana from Maryland and Virginia. We provide a tabular key to aid in identification of the named species of Moraria in North America.
\end{abstract}

Key words: Copepoda, Harpacticoida, Laurentian Great Lakes, taxonomy, new species, Moraria

\section{Introduction}

In collections from the Laurentian Great Lakes made by Patrick L. Hudson and associates of the Great Lakes Science Center at Ann Arbor, Michigan, there appeared a species of the harpacticoid copepod genus Moraria that could not be attributed to any presently known taxon in the genus. We describe the new species and compare it to congeners.

The taxonomic literature on this genus is widely scattered and there is no recent revision. We review records of Moraria from North and Central America, and discuss the known geographical distributions and habitats of all the named North American species. To aid readers, references to the original descriptions of the taxa mentioned are provided, although some of these articles are not cited directly in the text. 
Copepods were fixed and preserved in $70 \%$ ethanol. For taxonomic description, individual specimens were transferred to glycerin and then to lactic acid. Drawings were made from either whole specimens temporarily mounted in lactic acid, or from dissected specimens mounted on slides in commercial CMC-10® medium (Masters Chemical Company, Wood Dale, Illinois) to which a little chlorazol black E stain had been added. Specimens were drawn using a Leica DMLB ${ }^{\circledR}$ compound microscope equipped with differential interference contrast illumination, at magnifications of 400, 1000, or 2000x. The photomicrographs were taken with a SP100® cooled color digital camera mounted on a Zeiss Photo-Microscope III ${ }^{\circledR}$. The type specimens have been deposited in the collections of the National Museum of Natural History (NMNH), Smithsonian Institution, Washington, D.C. (USNM catalog numbers). Voucher specimens of some other species mentioned have been deposited either in the NMNH or in the Virginia Museum of Natural History, Martinsville, Virginia (VMNH).

\section{Description}

Family Canthocamptidae Brady 1880

Genus Moraria T. and A. Scott 1893

Moraria hudsoni n. sp.

Figures 1- 6

Synonymy: Moraria laurentica.-Hudson et al. 1998: 34 [partim].

Moraria mrazeki.-Hudson et al. 1998: 34 [partim].

Material examined: Holotype female, dissected on slide (USNM 1007895); allotype male, dissected on slide (USNM 1007896); and 7 female, 5 male, and 6 copepodid paratypes, ethanol-preserved (USNM 264250); all from Michigan: Mackinac County: Lake Huron: Prentiss Bay north of Highway M134, 45 59'26"N, 084 13'37"W, collected with hand grab, 18 August 1994, coll. P.L. Hudson.

Non-paratype specimens: 1 male, Michigan: Lake Michigan: Trails End Bay, $45^{\circ} 44^{\prime} 50^{\prime \prime} \mathrm{N}, 084^{\circ} 48^{\prime} 06^{\prime \prime} \mathrm{W}$, among aquatic vegetation, water depth 30-60 cm, 6 June 1994 , coll. P.L. Hudson (USNM 259905). 1 female and 1 copepodid, Michigan: Lake Michigan: Trails End Bay, location as above, 15 August 1994, coll. P.L. Hudson (USNM 278064). 2 females, Michigan: Mackinac County: Lake Huron: Prentiss Bay: Whitefish Point, Cedar Camp, 4558'49"N, 084¹3'52"W, 7 June 1996, coll. P.L. Hudson (USNM 284307). 7 females, Michigan: Mackinac County: Lake Huron: Prentiss Bay, north of Highway M134, among Carex, water depth 40-50 cm, 45 59'26"N, 084²13'37"W, 9 May 1996, coll. P.L. Hudson (USNM 284313). 4 females, Michigan: Mackinac Co.: Lake Huron: Prentiss Bay, location as above, sedge meadow, surface grab, 15 May 2000, coll. P.L. Hudson (USNM 305420). 
Female: Length of holotype, from tip of rostrum to tips of caudal rami (specimen extended in lactic acid), $448 \mu \mathrm{m}$; range of lengths of 7 female paratypes (in glycerin), 392$424 \mu \mathrm{m}$.

Body (Figs. 1, 2, 3A) compact, tapering antero-posteriorly. Except for cephalosome, body with numerous rows of minute hairs; integument covered with refractile points, appearing as tiny pores (arrowed circle in Fig. 2B). Rostrum distinct from cephalosome, bluntly triangular with 2 subapical sensilla. Cephalosome with ovoid dorsal hyaline window; pedigers 2 and 3 each with paired lateral hyaline windows (Fig. 2A). Hyaline frills of pedigers 2-4 smooth; frills of pediger 5, genital double-somite, and abdominal somites 2 and 3 crenate. Genital double-somite with row of spines extending dorsally and laterally along posterior margin; abdominal somites 2 and 3 each with row of spines along entire posterior margin. Urosomite with spines along lateral and ventral margins.
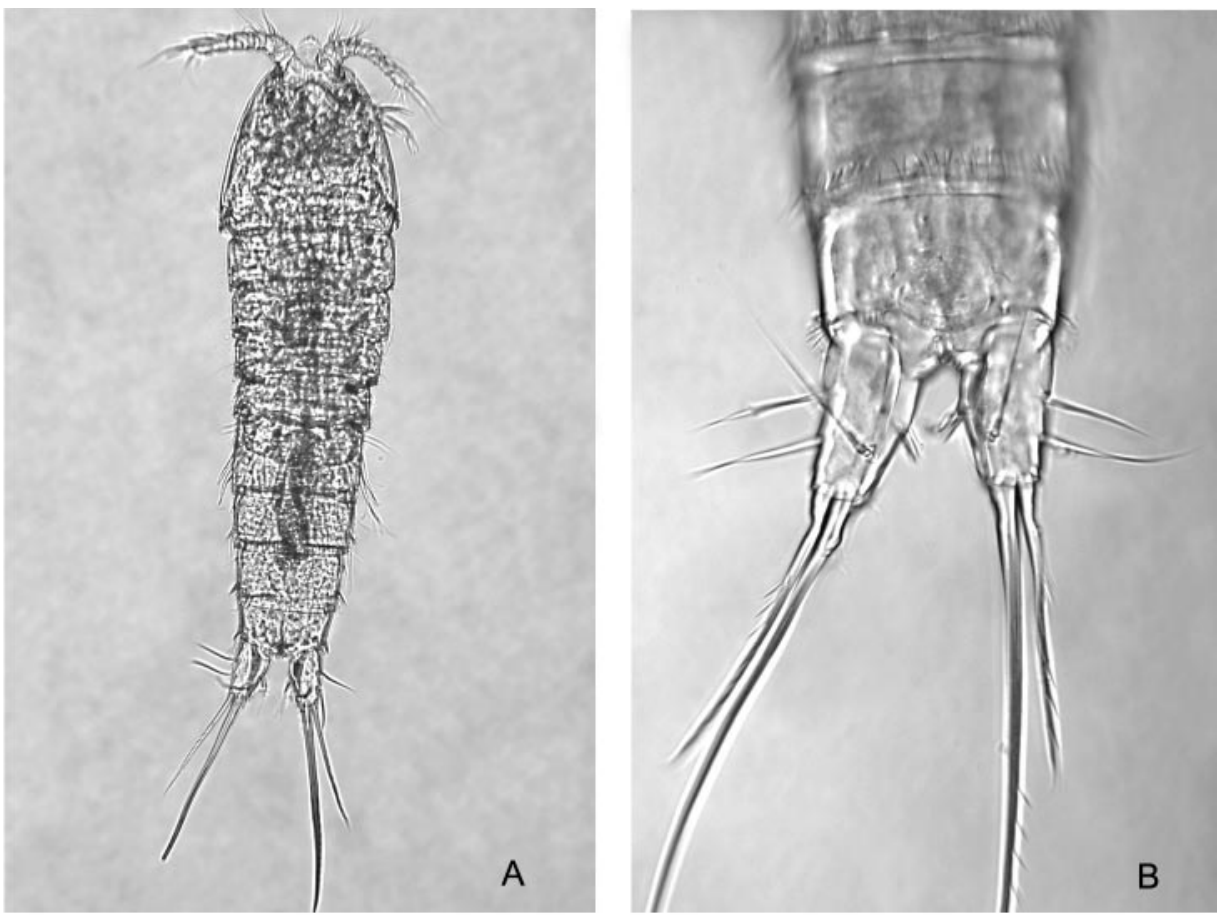

FIGURE 1. Moraria hudsoni n. sp., female. A, habitus, dorsal view; B, posterior urosomites and caudal rami, dorsal view.

Anal operculum (Figs. 2B, 3C) rounded, reaching approximately to posterior end of urosomite, its free margin bare.

Caudal ramus (Figs. 1B, 2, 3A-D) about 2 times longer than wide, tapering posteriorly and with prominent longitudinal dorsal crest extending to $4 / 5$ length of ramus and ending in acute point. Ramus bearing 2 lateral (outer) setae (anterior lateral seta also with tiny hair at its base); 3 terminal setae of which the medial (inner) terminal seta is short and slender, 

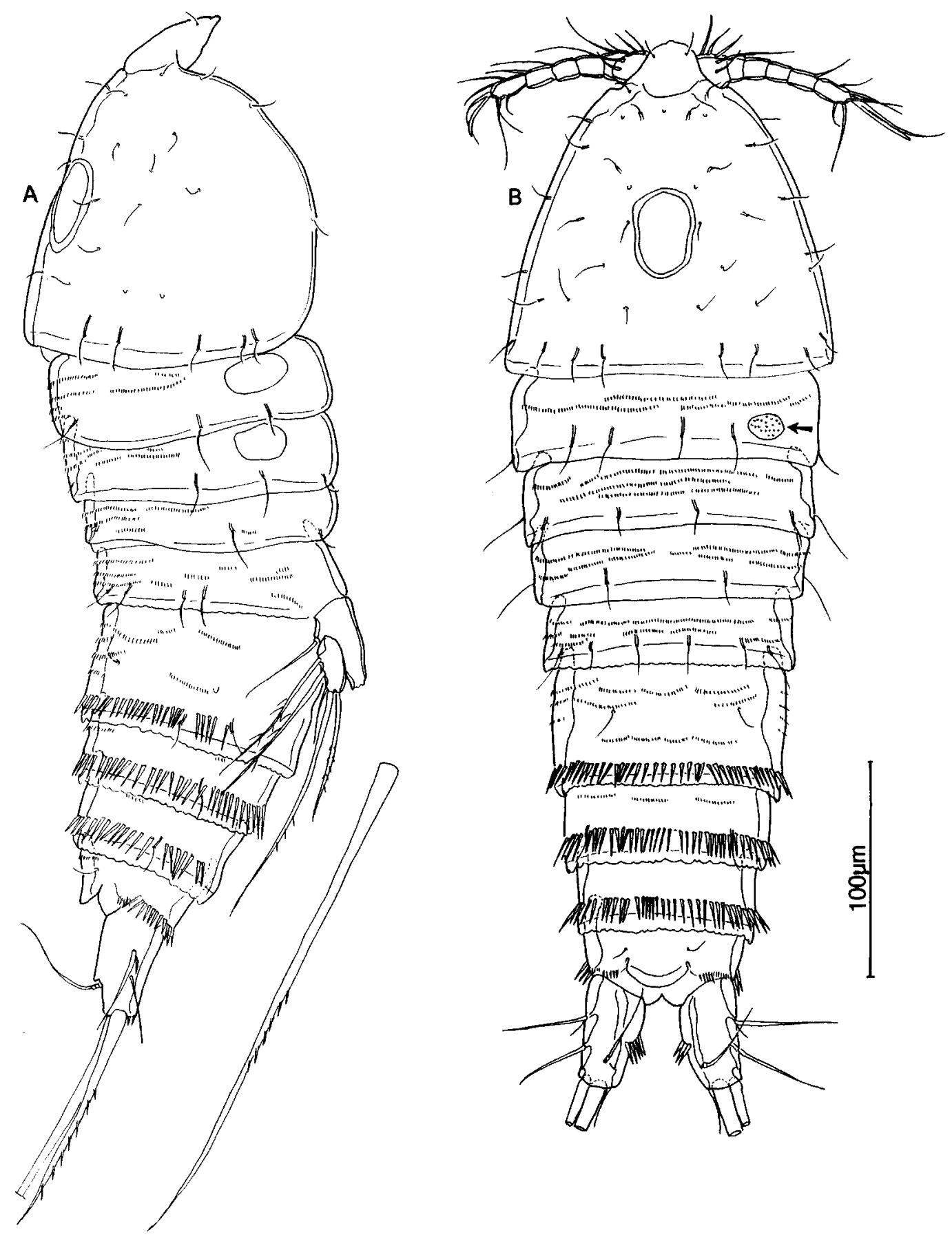

FIGURE 2. Moraria hudsoni n. sp., female. A, habitus, lateral view (longest terminal caudal seta shown separately); B, habitus, dorsal view (arrow indicates detail of integumental points, which cover most of the body). Scale bar applies to all figures. 


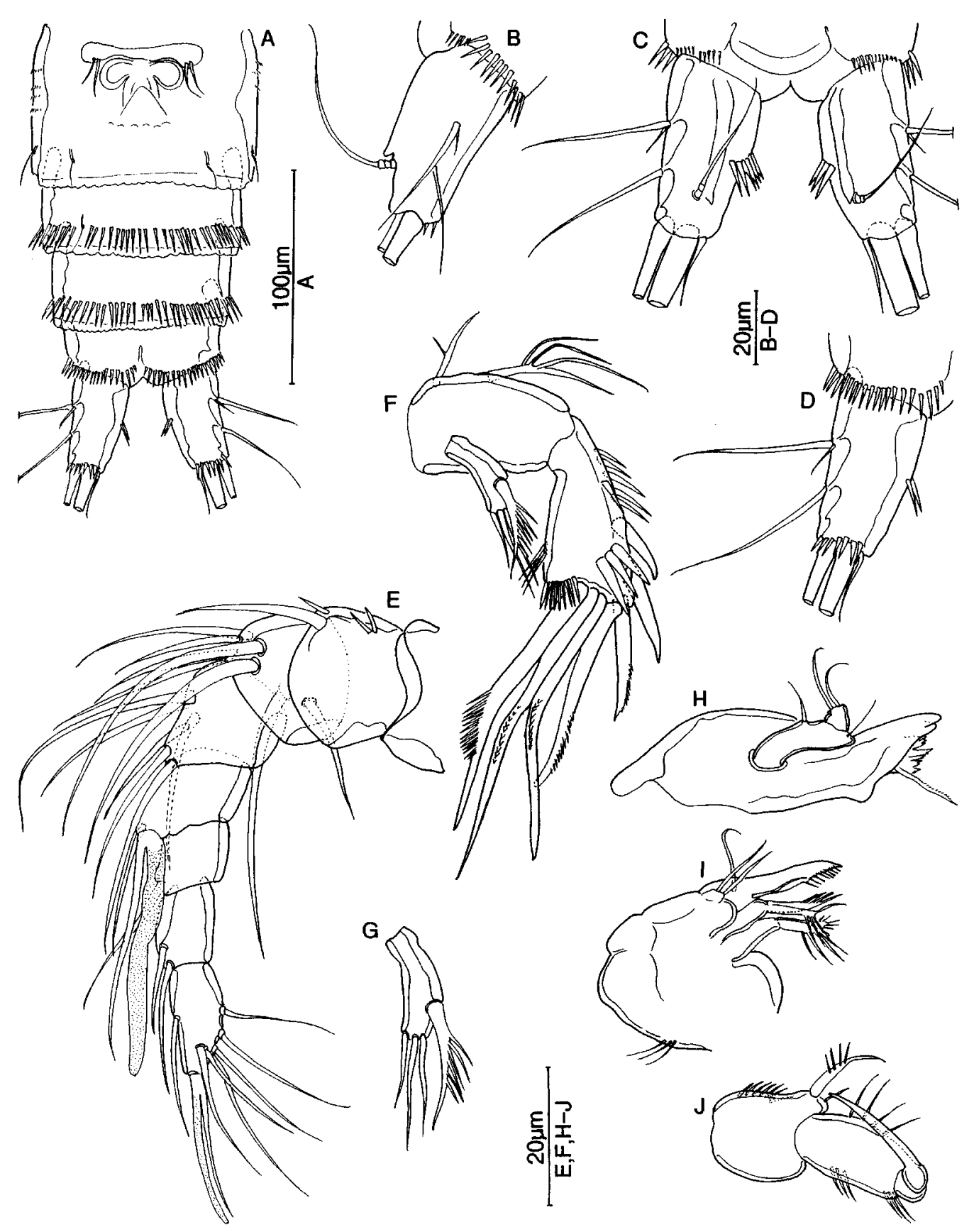

FIGURE 3. Moraria hudsoni n. sp., female. A, Abdomen, ventral view; B, caudal ramus, lateral view; C, anal operculum and caudal rami, dorsal view; D, caudal ramus, ventral view; E, antennule; F, antenna; G, antennal exopodite, enlarged; H, mandible; I, maxilla; J, maxilliped.

Antennule (Fig. 3E) 7-segmented, set on prominent base; segments 1-7 bearing respectively, 1, 8, 6, 2, 1, 2, and 8 setae, segments 4 and 8 also each bearing aesthetasc. 
Antenna (Fig. 3F, G) with allobasis; exopodite a single segment bearing 1 large stout spinulose seta on margin and 3 slender smooth setae terminally.

Mandible (Fig. 3H), endopodite with 2 apical setae.

Maxillule (not illustrated), precoxal arthrite with 7 spines and 2 setae; coxa with apical spine; basis with apical spine and 2 subapical setae.

Maxilla (Fig. 3I), syncoxa with 2 endites, each with 2 plumose terminal setae; basis with spatulate spinulose spine and 2 pairs of setae.

Maxilliped (Fig. 3J), basis with large plumose distal seta.

Legs 1-4 (Fig. 4A-D) with 3-segmented exopodites and 2-segmented endopodites. Couplers (intercoxal sclerites) without ornament. Leg 1, endopodite slightly shorter than exopodite, segment 1 with slender seta on mediodistal corner, segment 2 with 3 terminal and subterminal setae of which middle seta is about 3 times longer than endopodite. Legs 2-4, exopodite segment 3 respectively with 4,4 , and 5 socketed spines and setae; endopodite segment 1 with 1 , and segment 2 respectively with 2, 3, and 3 setae.

Leg 5 (Fig. 4E), baseoendopodites separated, medial lobe of each leg bearing 6 setae. Exopodite distinct from baseoendopodite, ovoid, reaching about to end of baseoendopodite, usually bearing 5 setae, but holotype female with 6th seta on medial margin (arrowed in figure).

Preserved specimens colorless.

Male: Length of allotype, from tip of rostrum to tips of caudal rami (specimen extended in lactic acid), $420 \mu \mathrm{m}$; range of lengths of 5 male paratypes (in glycerin), 360$400 \mu \mathrm{m}$.

Body (Fig. 5) like that of female in general shape, number and position of hyaline windows, and ornamentation; in particular, spine rows on all urosomites complete dorsally. Anal somite, operculum, and caudal rami as in female.

Antennule (Fig. 6A) apparently of 9 segments, segments 4 and 9 each with aesthetasc.

Antenna and mouthparts as in female.

Legs 1-4, coxopodites, basipodites, exopodites, endopodite of leg 1, and couplers as in female; spine on mediodistal corner of basipodite of leg 1 also similar to that of female. Legs 2-4 endopodites 2-segmented, all dimorphic. Leg 2 endopodite (Fig. 6B, C), segment 1 with 1 spinulose seta on medial margin and 2 stout lateral spines; segment 2 with 2 long slender plumose setae. Leg 3 endopodite (Fig. 6D), segment 1 with 1 spinulose seta and 1 spine on medial margin, and 2 spines on lateral margin; segment 2 with stout apophysis having simple acute tip, and 2 terminal setae of which the medial seta is longer and spinulose. Leg 4 endopodite (Fig. 6E, F, G) segment 1 with spine on medial surface, larger spine on laterodistal corner, and smooth slender seta on mediodistal corner. Leg 4 segment 2, lateral margin with 1 or 2 spines; apex with doubly recurved, corkscrew-shaped spine; and medial margin with 3 or 4 setae, of which 1 seta is at least twice as long as the others, relatively stiff, and spinulose, plus 1 tiny, apparently unsocketed setiform process near base of apical spine. 


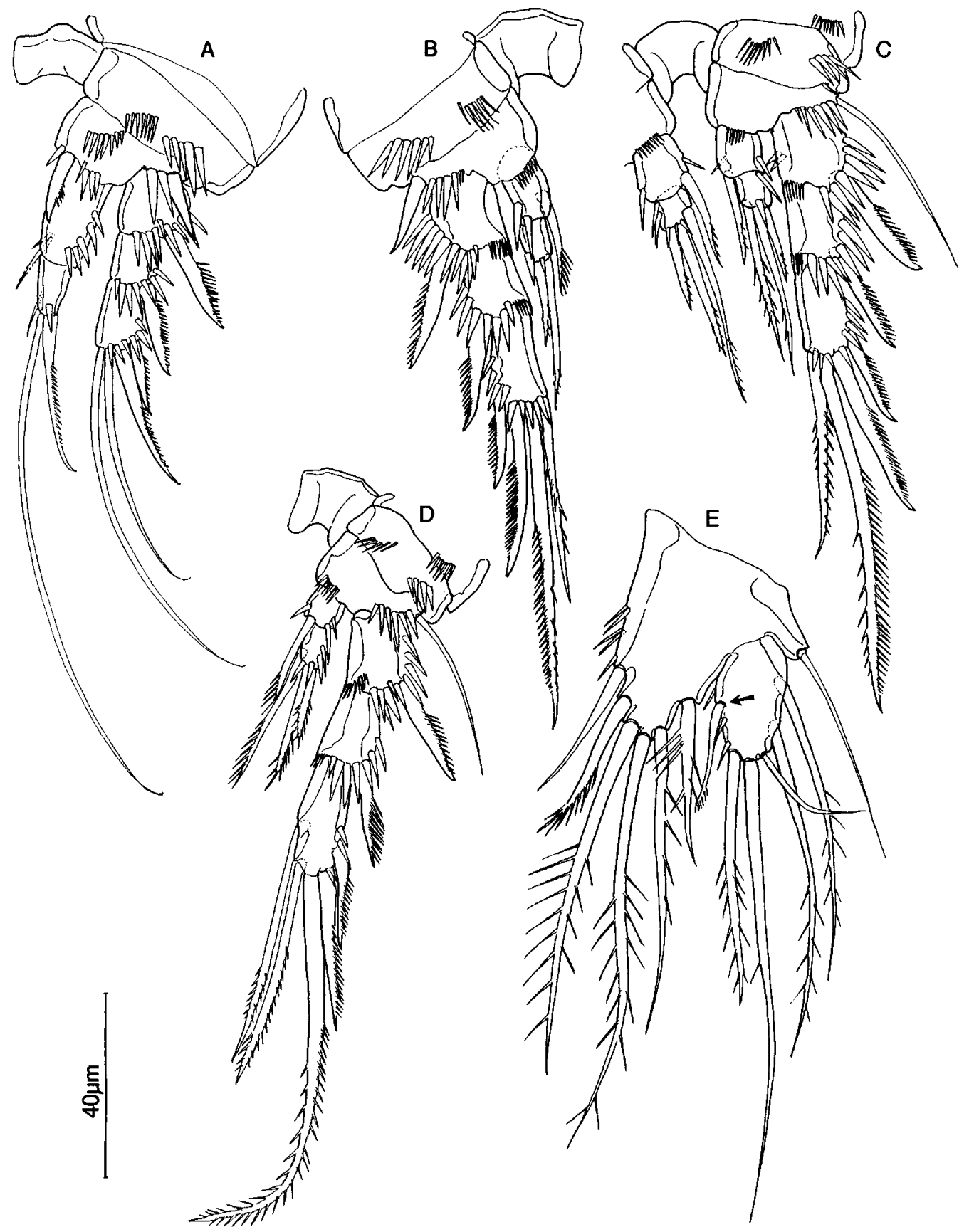

FIGURE 4. Moraria hudsoni n. sp., female. A, Left leg 1 and coupler; B, right leg 2 and coupler; $\mathrm{C}$, left leg 3, coupler, and right leg 3 endopodite; D, leg 4; E, leg 5 (arrow indicates 6th seta, present in holotype female but not in most individuals examined).

Leg 5 (Fig. 6H), baseoendopodites partly fused; medial lobe bearing 2 stout, spinulose setae; exopodite with 5 setae. 
Etymology: The species appellation honors the collector, Patrick L. Hudson, in appreciation of his many contributions toward understanding the ecology and taxonomy of the fauna of the Laurentian Great Lakes.
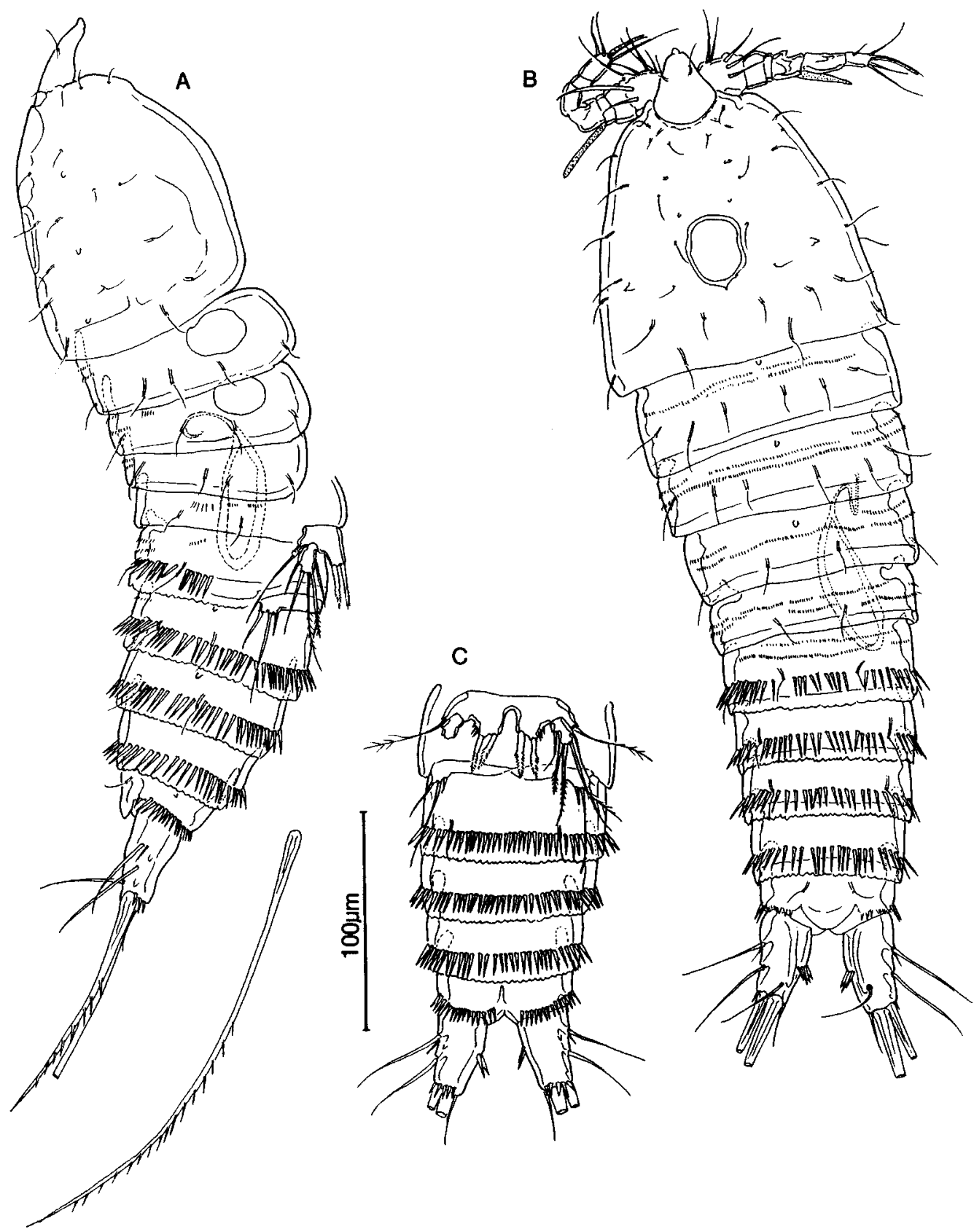

FIGURE 5. Moraria hudsoni n. sp., male. A, habitus, lateral view (longest terminal caudal seta shown separately); B, habitus, dorsal view; C, urosome, ventral view. Scale bar applies to all figures. 

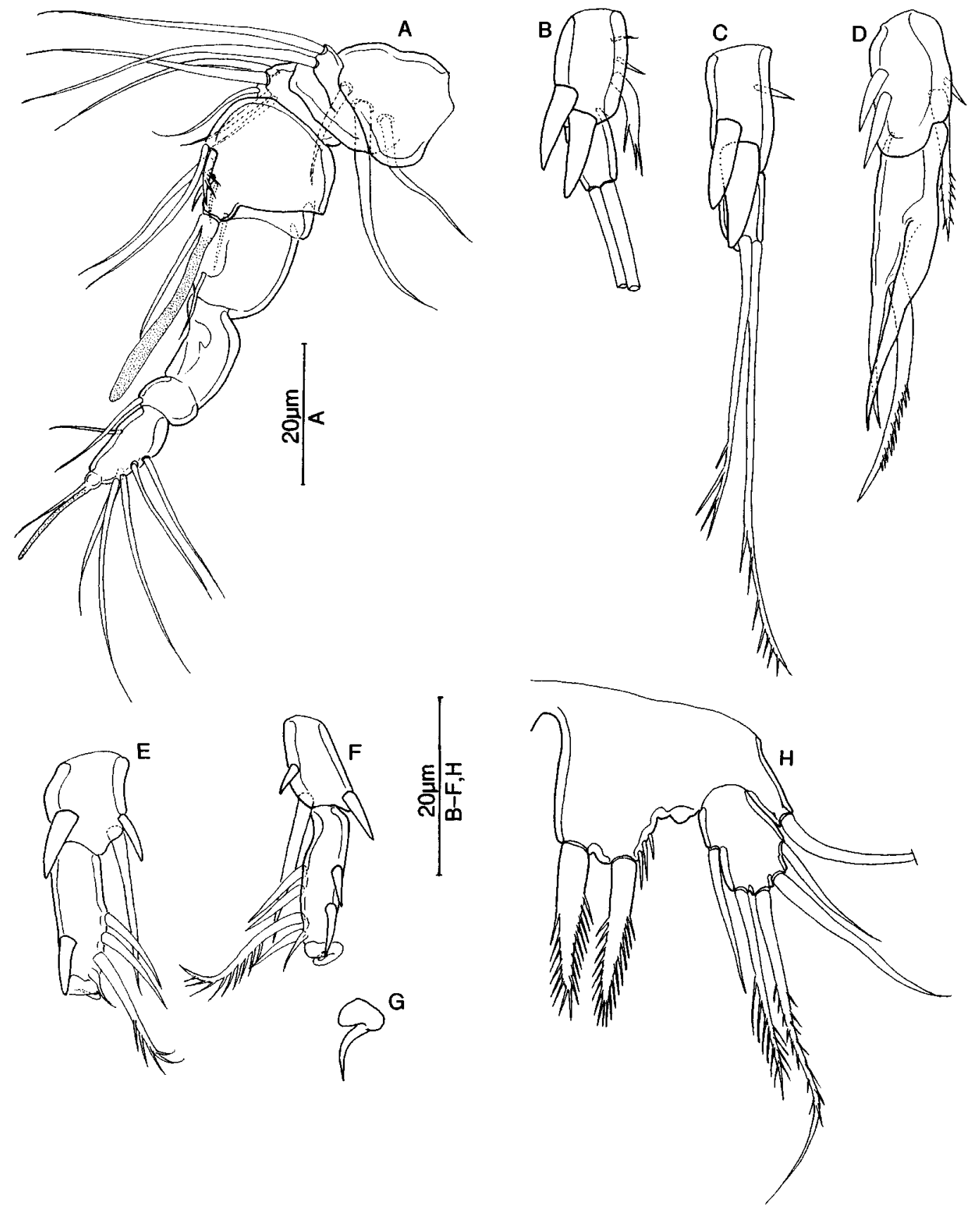

FIGURE 6. Moraria hudsoni $\mathbf{n}$. sp., male. A, antennule; B, leg 2 endopodite, frontal; C, leg 2 endopodite, lateral-oblique view, showing terminal setae; D, leg 3 endopodite; E, right leg 4 endopodite of allotype specimen, lateral-oblique view; F, left leg 4 endopodite of allotype specimen, frontal view; G, terminal spine of leg 4 endopodite of allotype specimen, oblique view, enlarged; $\mathrm{H}$, leg 5. 
The primarily boreal harpacticoid genus Moraria includes approximately 62 named species and subspecies. In the most recent taxonomic review, Lang (1948) recognized 22 valid species. Most of the taxa added since then are members of the subgenus Baikalomoraria Borutsky 1931, which is found mainly in Siberia and Mongolia; many of these were described by Borutsky (1931, 1952, 1972). The remaining species, all in subgenus Moraria, occur in Europe, temperate Asia, and North America. Since 1948, nine new species have been described from Europe, four from Asia, and two from North America. Dussart and Defaye (1990), in their world checklist of continental harpacticoid copepods, included nearly all of the taxa in the genus and commented briefly on taxonomic problems associated with some of them. Since then, four new species have been described: $M$. tsukubaensis Kikuchi 1991a from central Japan, M. terrula Kikuchi 1991b from northern Japan, M. jana Karanovic 1997 from Montenegro, and M. alpina Stoch 1998 from the Italian Alps. Stoch (1998) also described the male of M. pectinata radovnae Brancelj 1988, a species of small alpine rivers in Slovenia, and raised the taxon to species rank. Brancelj (2001) provided additional details of the morphology of M. radovnae and expanded its distribution in Slovenia.

In the Americas, the known range of the genus extends from the Arctic to Honduras. No species is known from South America. Löffler (1962) described a new species from Chile, Moraria (Kühneltiella) neotropica, for which he proposed the new subgenus Kühneltiella. Cicchino and Ringuelet (1977) correctly transferred M. (K.) neotropica to the austral genus Antarctobiotus Chappuis 1930, thus invalidating the subgenus Kühneltiella. A second species from Chile, M. kummeroworum, described by Ebert and Noodt (1975), is also a member of Antarctobiotus.

Species of Moraria have been reported several times from southern Mexico or Central America, but none has actually been described from the region. Wilson (1936) identified M. cristata among the copepods collected by A.S. Pearse from a ciénaga (swamp) on the Yucatán Peninsula in Mexico. However, Reid (1990), Suárez-Morales et al. (1996), and Suárez-Morales and Reid (1998) included Wilson's record in their checklists for Mexico and the Yucatán only with reservations, because no voucher specimens exist and no species of Moraria has appeared in extensive collections made in recent decades from benthic habitats of the peninsula. Löffler (1972) reported the presence of members of the genus in lakes and ponds in high-mountain regions of southern Mexico and western Guatemala, but did not describe them. In an unpublished thesis, Ebert (1976) described a new species $M$. hondurica collected from bromeliads in a cloud forest at an altitude of about $2000 \mathrm{~m}$ in the Cerro Uyuca in Honduras, but unfortunately this name remains unavailable. Ebert's (1976) report established the southernmost record of the genus in the Americas.

In North America north of Mexico, seven species are currently recognized. Carter (1944) listed four species: M. laurentica Willey 1927, M. affinis Chappuis 1927, M. cristata Chappuis 1929, and M. virginiana Carter 1944. She assigned M. americana Chappuis 
1927 as a subspecies of $M$. laurentica, in agreement with the earlier opinion of Chappuis (1931). Wilson (1956a) followed Carter's arrangement, and added the European species $M$. duthiei (T. and A. Scott 1896) and M. mrazeki T. Scott 1903 from collections made in Alaska and Canada. Later, Wilson and Yeatman (1959) apparently accepted the opinion of Lang (1948) in considering M. americana as a junior synonym of M. laurentica, and included a total of six species in their key. Flössner (1988) described a seventh species, $M$. arctica, from Disko Island and the Northwest Territories. The discovery of M. hudsoni $\mathrm{n}$. sp. brings the total to eight.

North American records of species of Moraria are concentrated, inevitably, in the few parts of the continent where interested workers have collected from suitable habitats. Members of this genus live mostly in moist soil and terrestrial mosses, springs and seeps, bogs, decaying leaf litter, treeholes, and similar situations which are not often investigated for copepods. Nevertheless, most of the North American species have been reported from widely scattered locations and a variety of habitats, some subterranean. The published records and habitats of all the species, along with new geographical records for some, are listed in the following paragraphs.

Willey (1927) collected and described M. laurentica from springs and a Sphagnum bog in several locations in the Laurentian Mountains of Québec. Strayer (1989) found it in the hyporheic sediments of a creek in southeastern New York, where it was not abundant. A single population ascribed to this species was reported by Hudson et al. (1998) from nearshore substrate and wetlands in the Les Cheneaux Island area of Lake Huron. Moraria americana (now considered a synonym of $M$. laurentica) was described by Chappuis (1927) from a mossy valley near West Orange, New Jersey.

Moraria affinis was described by Chappuis (1927) from a park near Pelham Bay, New York. The species was not reported again until Wilson (1956a) recorded it from near Anchorage, Alaska, in moss on a cliff over which a meltwater stream was flowing. Strayer (1989) found M. affinis in stream hyporheic sediments and other groundwater-related habitats such as springs and seeps in southeastern New York. Hudson et al. (1998) reported specimens tentatively ascribed to $M$. affinis from periphyton-covered rocks brought up from Six Fathom Bank, and from shallower nearshore sediments in Prentiss Bay in Lake Huron. The known distribution was recently extended considerably southward by two finds in south-central Virginia: in wet leaf litter beside a stream in a mixed hardwood and hemlock forest on the eastern slope of the Blue Ridge Mountains in Patrick County; and in wet moss on rocks in a tiny spring-fed stream running through mixed hardwood forest in the central Piedmont, Prince Edward County (J. W. Reid, unpublished data; voucher specimens in VMNH).

Moraria cristata was described by Chappuis (1929) from females collected from pools ("rassemblements d'eau") in Donnaldson Cave, Indiana. Later, Chappuis (1931) expanded the description of the female and described the male from specimens collected in wet mosses near Columbus, Ohio. The same species was reported from plankton sam- 
ples in Lake Ontario by Czaika (1974, 1978). Nalepa and Quigley (1980) found it in benthic samples taken at depths of 11 to $23 \mathrm{~m}$ in Lake Michigan, near the mouth of the Grand River. Shiozawa (1991) reported it from the bed of one of nine low-order streams sampled in Minnesota. Hudson et al. (1998) found one specimen in sandy nearshore substrate in the Les Cheneaux Islands area, Lake Huron. Moraria cristata was found among decaying leaves in a spring in Rock Creek National Park, District of Columbia (Reid 1996), and in another spring in Rock Creek Stream Valley Park in adjacent Maryland (J.W. Reid and T. Ishida, unpublished data; voucher specimens in NMNH). Moraria cristata has also been found in several localities in Virginia: moss beside a spring in the Shenandoah National Park (J.W. Reid, unpublished data; voucher specimens in NMNH), a roadside seep in Patrick County, and moist streamside moss in Henry County (J.W. Reid, unpublished data, including collections by R. L. Hoffman; voucher specimens in VMNH). It is relatively common in springs, seeps, and wet mosses in the Great Smoky Mountains National Park, North Carolina and Tennessee (J. W. Reid 1999 and unpublished data), and other unspecified localities in North Carolina (Clamp 1999).

Moraria virginiana was described by Carter (1944) from small springs near Mountain Lake in western Virginia. Carter and Bradford (1972) reported it as numerous in Sphagnum bogs near Mountain Lake, and described the male and the copepodid developmental stages. It is common and sometimes numerous in springs, seeps, and wet mosses, and is sometimes found together with M. cristata in the Great Smoky Mountains National Park, North Carolina and Tennessee (Clamp 1999; Reid 1999; J. W. Reid, unpublished data). The species was recently collected in two additional locations in the Blue Ridge Mountains in south-central Virginia: in wet leaf litter in a seep on Buffalo Mountain in Floyd County, and among decaying leaves in a roadside seep in the Dan River valley, Patrick County (J. W. Reid, unpublished data from collections by R. L. Hoffman; voucher specimens in VMNH). Its range extends at least to the Maryland coastal plain, where it was found in a spring in Jug Bay Wetlands Sanctuary, Anne Arundel County (drainage basin of the Patuxent River), by A. Norden in 1994 (J. W. Reid, unpublished data; voucher specimens in USNM).

Wilson (1956a) reported that M. duthiei (T. \& A. Scott 1896) is one of the most common harpacticoids in Yukon Territory and Alaska. She recorded it from the margin of Lake Tikchik in southwestern Alaska (Wilson 1956b; 1958). Chengalath and Shih (1994) listed the species from Alaska, Yukon Territory, western Northwest Territories, British Columbia, Alberta, and Saskatchewan. Hudson et al. (1998) gave new records from the stomachs of fish caught in lakes Huron and Michigan. Moraria duthiei is widely distributed in northern Europe and Russia (Lang 1948), and was redescribed in detail by Gurney (1932).

Wilson (1956a) also added M. mrazeki T. Scott 1903 to the North American list, from collections in Alaska. Shiozawa $(1986 ; 1991)$ found it in the bottom sediments of three of nine streams sampled in Minnesota; in one of these streams the population was dense (over 14,000 individuals per $\mathrm{m}^{2}$ ). Chengalath and Shih (1994) listed this species from 
Alaska and the same Canadian provinces as M. duthiei. Ward and Voelz (1994) reported it as being common in hyporheic sediments at one location in the South Platte River, Colorado. Hudson et al. (1998) reported M. mrazeki from nearshore sediments in lakes Superior, Huron, Michigan, and Ontario, and the stomach of a larval fish in the St. Marys River. Clamp (1999) reported M. mrazeki from North Carolina (locality and habitat unspecified), based on information from D. J. Williams. Outside North America, M. mrazeki occurs widely in northern and central Europe, Russia, and Greenland (Lang 1948). The female was redescribed by Gurney (1932).

Flössner (1988) added a new species, $M$. arctica, from Disko Island in Greenland and three localities in the Northwest Territories in Canada. The specimens were all collected in low numbers (one to four females) from interstitial groundwaters: on Disko Island at Rodeelv, and in Canada from Bear Lake near Fort Franklin, from the Caribou River near Inuvik, and from the shore of Lake Yellowknife near Yellowknife.

Several males and females of an unidentified species of Moraria were collected from the gravel bottom of a stream in Fuller's Cave in Greenbrier County, West Virginia, by Starr (1968). Starr's copepod identifications were verified by T. E. Bowman, and the records from Starr's unpublished report were included in the checklist of Holsinger et al. (1976). According to Starr's account, the cave stream is fed by runoff from surrounding impermeable caprock and by intermittent surface streams in the valley, and is highly sensitive to surface rainfall. All the other copepod species that Starr collected in the three caves that he examined are primarily epigean and troglophilic: Attheyella carolinensis, Attheyella illinoisensis, Bryocamptus nivalis, Bryocamptus vejdovskyi, Bryocamptus zschokkei, and Bryocamptus sp. It will be impossible to pursue this record further without making new collections, since apparently none of Starr's material was deposited in either the NMNH or the Peabody Museum of Natural History, Yale University.

Species are distinguished mainly on the basis of the chaetotaxy of the swimming legs (pereopods) 1-4 in the female, the nature of the modified endopodites of legs 2-4 in the male, the shape and ornamentation of the caudal rami, and the ornamentation (distribution of spine rows) of the urosome. Moraria hudsoni has both an unusual chaetotaxy in the female, and unusual urosomal ornamentation. Only one variable species, M. arboricola Scourfield 1915 from England, may have two, three, and three setae respectively on the terminal segments of the endopodites of legs 2-4 in the female, as in M. hudsoni, since the range of variation reported for that species includes these numbers. However, M. arboricola differs from M. hudsoni in having only four setae on leg 4 exopodite segment 3, two rows of spines on the medial surface of the caudal ramus, and in other characters. In most species, the rows of spines fringing the posterior margins of the urosomites extend only ventrally and laterally, and do not ring the entire urosomite as in M. hudsoni. For M. valkanovi Michailova-Neikova 1973 from Bulgaria, only the male has been described, and therefore the nature of the chaetotaxy of legs 2-4 in the female is not known. In M. valkanovi the urosomal spine rows do not extend dorsally, and this species also differs from 
M. hudsoni in the chaetotaxy of legs 2 and 4 and in having the medial surface of the caudal ramus without spines.

In their list of cyclopoid and harpacticoid copepods of the Great Lakes, Hudson et al. (1998) reported Moraria affinis, M. cristata, M. duthiei, M. laurentica, and M. mrazeki. In reviewing earlier identifications, P. L. Hudson, J. W. Reid, and L. T. Lesko realized that they had consistently identified specimens of M. mrazeki and M. hudsoni as M. laurentica. In fact, only one population could be assigned with confidence to M. laurentica. Revised records of the other species are summarized in a general key to the harpacticoid copepods of the Great Lakes (Lesko et al. 2003). The best "field marks" for distinguishing M. hudsoni from other congeneric species which are present in the Great Lakes region are the complete spine rings encircling the urosomites; the rounded, non-produced anal operculum; and the prominent dorsal crest on the caudal ramus.

Table 1 provides some morphological characters to aid in distinguishing M. hudsoni and the other presently known North American species of Moraria. The table is constructed as a tabular key, and is most efficiently used if all the characters are observed on a given specimen, listed in order, and then matched to the characters in the table read from left to right and from top to bottom. Many taxonomically useful characters of harpacticoid copepods are meristic in nature and are especially appropriate for use in a tabular key, as demonstrated by the successful and widely used key of Wells (1976) and its supplements. Tabular keys have several advantages over the standard dichotomous keys (Newell 1970; 1976), such as providing a good deal of redundancy and much more information on each taxon. This is an important consideration in the case of tiny harpacticoids, which may be difficult to observe and which may also vary in certain characters. For these reasons most of the characters in Table 1 were selected to be easily visible without dissecting the animals, and do not necessarily have any systematic importance. The original taxonomic descriptions and redescriptions should be consulted in order to confirm identifications.

The conservation status of most of the named North American species does not seem to be a matter for concern, in view of their varied habitats and because recent collections in new geographical regions have expanded the known distributions of several. For instance, for some decades $M$. virginiana had been reported only from one small region in southwestern Virginia, but is now known from Maryland, North Carolina, and Tennessee as well. The range of M. affinis, known from New York, the Great Lakes region, and Alaska, was extended far south to Virginia. Therefore, most should be evaluated as being of "Least Concern (LC)" under the IUCN categories (IUCN 2001). It would be desirable to attempt to recollect and evaluate the undescribed species reported by Starr (1968) from West Virginia. At present, M. hudsoni is known only from Trails End Bay on Lake Michigan, at the northern tip of Michigan's Lower Peninsula, and from Prentiss Bay on Lake Huron, on the southern shore of the Upper Peninsula. These localities are only about $75 \mathrm{~km}$ from each other. All of the collections were made in nearshore waters, from among aquatic vegetation or rocky rubble, over a six-year period. Because M. hudsoni has so far been found 
only in this small region and in a rather restricted habitat, after several years of efforts to collect copepods from all conceivable substrates and habitats throughout much of the Great Lakes region (Hudson et al. 1998; Lesko et al. 2003), we consider that its conservation status should be regarded as "Data Deficient" (DD: IUCN 2001) and recommend that further efforts be made to collect it in other parts of the region.

TABLE 1. Some morphological characters distinguishing the species of Moraria recorded from North America: 1, Rows of large spines distributed along only ventral and lateral posterior margins of urosomites; vs. completely encircling urosomites; 2, Anal operculum size, largely produced, far overlapping the base of the caudal ramus; or not produced, not reaching past the end of the anal somite; 3, Urosomal hyaline membranes, strongly serrate, weakly crenate, or smooth; 4, Anal operculum shape, rounded or triangular-acute; free margin of operculum smooth or denticulate; 5, Legs 2-4 of female, total number of setae on terminal segment of endopodite; 6 , Row of spines on medial surface of caudal ramus, present or absent.

\begin{tabular}{|c|c|c|c|c|c|c|}
\hline Species & $\begin{array}{c}1 \\
\text { Urosomal } \\
\text { spines }\end{array}$ & $\begin{array}{c}2 \\
\text { Anal opercu- } \\
\text { lum size }\end{array}$ & $\begin{array}{c}3 \\
\text { Urosomal } \\
\text { membrane }\end{array}$ & $\begin{array}{c}4 \\
\text { Anal opercu- } \\
\text { lum shape }\end{array}$ & $\begin{array}{c}5 \\
\text { P2-P4 } \\
\text { endopodite } \\
\text { (female) }\end{array}$ & $\begin{array}{c}6 \\
\text { Caudal } \\
\text { ramus } \\
\text { spines }\end{array}$ \\
\hline $\begin{array}{l}\text { M. hudsoni } \\
\text { n. sp. }\end{array}$ & Encircling & Not produced & Crenate & Round, smooth & $2,3,3$ & Present \\
\hline $\begin{array}{l}\text { M. laurentica } \\
\text { Willey }\end{array}$ & Ventral & Produced & Smooth & $\begin{array}{l}\text { Round- } \\
\text { triangular, } \\
\text { smooth }\end{array}$ & $3,4,4$ & $\begin{array}{c}\text { Present } \\
\text { (female) } \\
\text { Absent } \\
\text { (male) }\end{array}$ \\
\hline $\begin{array}{l}\text { M. virginiana } \\
\text { Carter }\end{array}$ & Ventral & Produced & Smooth & $\begin{array}{c}\text { Triangular, } \\
\text { smooth }\end{array}$ & $3,3,3$ & Present \\
\hline $\begin{array}{r}\text { M. cristata } \\
\text { Chappuis }\end{array}$ & Ventral & Not produced & Serrate & Round, smooth & $3,3,3$ & Present \\
\hline $\begin{array}{l}\text { M. arctica } \\
\text { Flössner }^{\mathrm{a}}\end{array}$ & Ventral & Not produced & Smooth & $\begin{array}{l}\text { Round, denticu- } \\
\text { late }\end{array}$ & $3,3,3$ & Present \\
\hline $\begin{array}{l}\text { M. duthiei } \\
\text { (T. \& A. Scott) }\end{array}$ & Ventral & Not produced & Smooth & $\begin{array}{c}\text { Triangular, } \\
\text { smooth }\end{array}$ & $4,5,4$ & Absent \\
\hline $\begin{array}{c}\text { M. mrazeki } \\
\text { T. Scott }\end{array}$ & Ventral & Not produced & Smooth & Round, smooth & $3,3-4,3-4$ & Present \\
\hline $\begin{array}{l}\text { M. affinis } \\
\text { Chappuis }\end{array}$ & Ventral & Not produced & Smooth & Round, smooth & $3,3,3$ & Absent \\
\hline
\end{tabular}

a The male of $M$. arctica has not been described. 
The Great Lakes Science Center, the Michigan Chapter of The Nature Conservancy, and the Coastal Zone Management Program of the State of Michigan provided support for Patrick L. Hudson's collecting activities. The National Museum of Natural History, Smithsonian Institution, provided research facilities to Janet W. Reid during the early stages of this project. Cheryl Bright, Geoff Keel, and especially Chad Walter of the Section of Invertebrate Zoology, Department of Systematic Biology, NMNH provided assistance with processing specimens and supplying essential literature from the C. B. Wilson Copepod Library. John R. Holsinger of Old Dominion University graciously provided a copy of the report by Starr (1968). Janet W. Reid is grateful to Teruo Ishida for his cordial permission to include an unpublished record of Moraria cristata. We thank Keith A. Crandall and two anonymous reviewers for their thoughtful recommendations. This article is Contribution 1239 of the U.S. Geological Survey Great Lakes Science Center, Ann Arbor, Michigan.

\section{References}

Borutsky, E.V. (1931) Materialen zur Harpacticidenfauna des Baikalsees. II. Zoologischer Anzeiger, 93(7-10), 263-273.

Borutsky, E.V. (1952) Fauna of U.S.S.R. Crustacea. 3(4). Freshwater Harpacticoida. Academy of Sciences of the U.S.S.R., Moscow-Leningrad, 424 pp. [In Russian. English translation, 1964. Israel Program for Scientific Translations, Smithsonian Institution and US National Science Foundation, Washington, D.C., 396 pp.].

Borutsky, E.V. (1972) Baikal Harpacticoida (Copepoda) in the Lake Khubsugul (Mongolia). Zoologichesky Zhurnal, 51(4), 490-495. [In Russian].

Brady, G.S. (1880) A Monograph of the Free and Semi-parasitic Copepoda of the British Islands, Vol. II. Ray Society, London, 182 pp., Plates 34-82.

Brancelj, A. (1988) Harpacticoids (Harpacticoida: Copepoda) from the Triglav National Park (Slovenia; Yugoslavia). Bioloski Vestnik, 36(4), 1-15.

Brancelj, A. (2001) Male of Moraria radovnae Brancelj, 1988 (Copepoda: Crustacea), and notes on endemic and rare copepod species from Slovenia and neighboring countries. Hydrobiologia, 453/454, 513-524.

Carter, M.E. (1944) Harpacticoid copepods of Mountain Lake, Virginia (with description of Moraria virginiana n. sp.). Journal of the Elisha Mitchell Scientific Society, 60(2), 158-166, Plates 65-67.

Carter, M.E. \& Bradford, J.M. (1972) Postembryonic development of three species of freshwater harpacticoid Copepoda. Smithsonian Contributions to Zoology, 119, 1-26.

Chappuis, P.A. (1927) Freilebende Süsswasser-Copepoden aus Nordamerika. 2. Harpacticiden. Zoologischer Anzeiger, 74, 302-313.

Chappuis, P.A. (1929) Copépodes cavernicoles de l'Amérique du Nord (note préliminaire). Bulletin de la Société des Sciences de Cluj, 4(2), 51-57.

Chappuis, P.A. (1930) Notes sur les copépodes. 4. Antarctobiotus Koenigi (Pesta). Bulletin de la Société des Sciences de Cluj, 5(2), 62-64. 
Chappuis, P.A. (1931) Campagne spéologique de C. Bolivar et R. Jeannel dans l'Amérique du Nord (1928). 4, Crustacés copépodes. Archives de Zoologie Expérimentale et Générale, 71(3), 345360 .

Chengalath, R. \& Shih, C.-t. (1994) Littoral freshwater copepods of northwestern North America: northern British Columbia. Verhandlungen der Internationale Vereinigung für Theoretische und Angewandte Limnologie, 25, 2421-2431.

Cicchino, G.N. \& Ringuelet, R.A. (1977) Copepodos del genero Antarctobiotus de Tierra del Fuego e Islas Malvinas (Rep. Argentina) (Harpacticoida - Canthocamptidae). Limnobios, 1(6), 207228.

Clamp, J.C. (Compiler) (1999) A Report on the Conservation Status of North Carolina's Freshwater and Terrestrial Crustacean Fauna. The Scientific Council on Freshwater and Terrestrial Crustaceans, North Carolina Wildlife Resources Commission, Raleigh, 93 pp. [Copy archived in C.B. Wilson Copepod Library, NMNH.]

Czaika, S.C. (1974) Crustacean zooplankton of southwestern Lake Ontario in 1972 during the International Field Year for the Great Lakes. Proceedings of the $17^{\text {th }}$ Conference on Great Lakes Research, Part 1, 1-16.

Czaika, S.C. (1978) Crustacean zooplankton of southwestern Lake Ontario in spring 1973 and at the Niagara and Genesee river mouth areas in 1972 and spring 1973. Journal of Great Lakes Research, 4, 1-9.

Dussart, B.H. \& Defaye, D. (1990) Répertoire mondial des Crustacés Copépodes des eaux intérieures. III. Harpacticoïdes. Crustaceana, Supplement, 16, 1-384.

Ebert, S. (1976) Natürliches System und Biogeographie der Familie Canthocamptidae (Copepoda Harpacticoidea) am Beispiel neotropischer Taxa. Ph.D. Dissertation, Christian-Albrechts-Universität, Kiel, 335 pp.

Ebert, S. \& Noodt, W. (1975) Canthocamptidae aus Limnopsammon in Chile (Copepoda Harpacticoidea). (Studien an chilenischen Grundwasser-Crustaceen VI). Gewässer und Abwässer, 5758, 121-140.

Flössner, D. (1988) New freshwater Canthocamptidae (Copepoda: Harpacticoida) from groundwaters of Canada and Greenland. Stygologia, 4(1), 26-41.

Gurney, R. (1932) British Fresh-water Copepoda, Vol. II. Harpacticoida. Ray Society, London, 336 pp.

Holsinger, J.R., Baroody, R.A. \& Culver, D.C. (1976) The invertebrate cave fauna of West Virginia. West Virginia Speleological Survey Bulletin, 7, 1-82.

Hudson, P.L., Reid, J.W., Lesko, L.T. \& Selgeby, J.H. (1998) Cyclopoid and harpacticoid copepods of the Laurentian Great Lakes. Ohio Biological Survey Bulletin, New Series, 12(2), 1-50.

IUCN (2001) IUCN Red List Categories: Version 3.1. IUCN Species Survival Commission, IUCN, Gland, Switzerland and Cambridge, U.K.

Karanovic, T. (1997) Two new species of harpacticoid copepods (Copepoda, Harpacticoida, Canthocamptidae) from Montenegro (Balkan Peninsula). Bulletin Zoölogisch Museum, Universiteit van Amsterdam, 16(1), 1-9.

Kikuchi, Y. (1991a) A new species of terrestrial harpacticoid copepods from forest litter in central Japan. Publications of the Itako Hydrobiological Station, 5, 27-34.

Kikuchi, Y. (1991b) A new species of the terrestrial Harpacticoida (Copepoda) from forest litter in northern Japan. Edaphologia, 47, 25-31.

Lang, K. (1948) Monographie der Harpacticiden, Vols. I, II. Nordiska Bokhandeln, Stockholm, $1682 \mathrm{pp}$.

Lesko, LT., Hudson, P.L., Reid, J.W. \& Chriscinske, M.A. (2003) Harpacticoid copepods of the Laurentian Great Lakes. U.S. Geological Survey Great Lakes Science Center, Ann Arbor, Michigan. Available from http://www.glsc.usgs.gov/greatlakescopepods/ Key.asp?GROUP=Harpacticoid\&ID=1 (accessd 26 May 2003). 
Löffler, H. (1962) Zur Systematik und Ökologie der chilenischen Süßwasserentomostraken. Beiträge zur Neotropischen Fauna, 2(3), 143-222.

Löffler, H. (1972) Contribution to the limnology of high mountain lakes in Central America. Internationale Revue der Gesamten Hydrobiologie, 57(3), 397-408.

Michailova-Neikova, M. (1973) Harpacticoida (Crustacea, Copepoda) reported from mountain waters in Bulgaria III. Lyulin Mountain (water moss and wet forest leaves). Annuaire de l'Université de Sofia, Faculté de Biologie: Zoologie, Physiologie et Biochimie des Animaux, 65(1), 89-99.

Nalepa, T.F. \& Quigley, M.A. (1980) The macro- and meiobenthos of southeastern Lake Michigan near the mouth of the Grand River, 1976-1977. National Oceanic and Atmospheric Administration Data Report ERL GLERL-17, Great Lakes Environmental Research Laboratory, Ann Arbor, Michigan (PB81-108169), $12 \mathrm{pp}$.

Newell, I.M. (1970) Construction and use of tabular keys. Pacific Insects, 12(1), 25-37.

Newell, I.M. (1976) Construction and use of tabular keys: addendum. Systematic Zoology, 25, 243250.

Reid, J.W. (1990) Continental and coastal free-living Copepoda (Crustacea) of Mexico, Central America and the Caribbean region. In: Navarro, D. \& Robinson, J.G. (Eds.), Diversidad Biológica en la Reserva de la Biosfera de Sian Ka'an, Quintana Roo, México. Centro de Investigaciones de Quintana Roo (CIQRO) and Program of Studies in Tropical Conservation, University of Florida, Gainesville, pp. 175-213.

Reid, J.W. (1996) Checklist of the Copepoda (Crustacea) of the District of Columbia. U.S. Geological Survey Patuxent Wildlife Research Center, Laurel, Maryland. Available from http:// www.mp1-pwrc.usgs.gov/blitz/biocopewash.html (accessed 26 May 2003) [Printed version archived in C.B. Wilson Copepod Library, NMNH.]

Reid, J.W. (1999) Great Smoky Mountains National Park: Crustacean Checklist: Copepods. Discover Life in America Foundation, Gatlinburg, Tennessee. Available from http://www.discoverlife.org/nh/cl/GSMNP/crustaceans_GSMNP.html (accessed 26 May 2003).

Scott, T. (1903) Some observations on British freshwater harpacticids. Annals and Magazine of Natural History, Series 7, 11, 185-196.

Scott, T. \& Scott, A. (1893) On some new or rare Scottish Entomostraca. Annals and Magazine of Natural History, Series 6, 15, 210-215, Plates 7, 8.

Scott, T. \& Scott, A. (1896) On some new and rare British Crustacea. Annals and Magazine of Natural History, Series 6, 18, 1-8, Plates 1, 2.

Scourfield, D.J. (1915) A new copepod found in water from hollows in tree trunks. Journal of the Quekett Microscopical Club, Series 2, 12, 431-440, Plates 24, 25.

Shiozawa, D.K. (1986) The seasonal community structure and drift of microcrustaceans in Valley Creek, Minnesota. Canadian Journal of Zoology, 64, 1655-1664.

Shiozawa, D.K. (1991) Microcrustacea from the benthos of nine Minnesota streams. Journal of the North American Benthological Society, 10(3), 286-299.

Starr, P.J. (1968) Cave Adaptations and Community Structure Among Some Harpacticoid Copepods. Unpublished Senior Honors Paper, Yale University, New Haven, 30 pp. [Copy archived in C.B. Wilson Copepod Library, NMNH.]

Stoch, F. (1998) Moraria alpina n. sp. and redescription of Moraria radovnae Brancelj 1988, new rank, from Italian and Slovenian Alps (Crustacea, Copepoda, Harpacticoida). Studi Trentini di Scienze Naturali - Acta Biologica, 73, 135-145.

Strayer, D. (1989) Crustaceans and mites (Acari) from hyporheic and other underground waters in southeastern New York. Stygologia, 4(2), 192-207.

Suárez-Morales, E. \& Reid, J.W. (1998) An updated list of the free-living freshwater copepods (Crustacea) of Mexico. The Southwestern Naturalist, 43(2), 256-265. 
Suárez-Morales, E., Reid, J.W., Iliffe, T.Y. \& Fiers, F. (1996) Catálogo de los Copépodos (Crustacea) Continentales de la Península de Yucatán, México. ECOSUR/CONABIO, México City, $296 \mathrm{pp}$.

Ward, J.V. \& Voelz, N.J. (1994) Groundwater fauna of the South Platte River system, Colorado. In: Gibert, J., Danielopol, D. \& Stanford, J.A. (Eds.) Groundwater Ecology, Academic Press, San Diego, California, pp. 391-423.

Wells, J.B.J. (1976) Keys to Aid in the Identification of Marine Harpacticoid Copepods. Department of Zoology, University of Aberdeen, Aberdeen, U.K., 215 pp.

Willey, A. (1927) Description of a new species of fresh-water copepod of the genus Moraria from Canada. Proceedings of the United States National Museum, 71(1), 1-12.

Wilson, C.B. (1936) Copepods from the cenotes and caves of the Yucatan Peninsula, with notes on cladocerans. Carnegie Institute of Washington Publication, 457, 77-88.

Wilson, M.S. (1956a) North American harpacticoid copepods. 1. Comments on the known freshwater species of the Canthocamptidae. 2. Canthocamptus oregonensis, n. sp., from Oregon and California. Transactions of the American Microscopical Society, 65(3), 290-307.

Wilson, M.S. (1956b) North American harpacticoid copepods: 3, Paracamptus reductus, n. sp., from Alaska. Journal of the Washington Academy of Sciences, 46(11), 348-351.

Wilson, M.S. (1958) North American harpacticoid copepods. 6. New records and species of Bryocamptus (subgenus Arcticocamptus) from Alaska. Transactions of the American Microscopical Society, 77(3), 320-328.

Wilson, M.S. \& Yeatman, H.C. (1959) Free-living Copepoda. In: Edmondson, W.T. (Ed.) Freshwater Biology, 2nd Edition. John Wiley \& Sons, New York, pp. 735-861. 